\title{
The respiratory chain is the cell's Achilles' heel during UVA inactivation in Escherichia coli
}

\begin{abstract}
Correspondence
Thomas Egli

egli@eawag.ch
\end{abstract}

Received 25 January 2010

Revised 6 April 2010

Accepted 14 April 2010
Franziska Bosshard, ${ }^{1,2}$ Margarete Bucheli, ${ }^{1}$ Yves Meur ${ }^{1}$ and Thomas Egli ${ }^{1,2}$

\author{
${ }^{1}$ Eawag, Swiss Federal Institute of Aquatic Science and Technology, PO Box 611, CH-8600 \\ Dübendorf, Switzerland \\ ${ }^{2}$ Institute of Biogeochemistry and Pollutant Dynamics, ETH Zürich, CH-8092 Zürich, Switzerland
}

\section{INTRODUCTION}

The deleterious effect of sunlight on enteric bacteria is used to improve the microbiological quality of drinking water by solar disinfection (SODIS), a treatment method in which the water is exposed to the sun in PET bottles for at least 6 hours. An epidemiological study during a cholera epidemic in Kenya showed an $88 \%$ reduction in diarrhoea cases among SODIS users (Conroy et al., 2001). Although the effectiveness of SODIS against enteric pathogens is well documented, the underlying cellular inactivation mechanisms are not well understood. We know from earlier studies that a similar sequential inactivation pattern can be observed in different enterobacteria such as Escherichia coli, Salmonella typhimurium and Shigella flexneri (Berney et al., 2006a; Bosshard et al., 2009), with total ATP contents being reduced and efflux pump activity lost early (>500 $\mathrm{kJ} \mathrm{m}^{-2}$ in E. coli), followed by a complete depolarization of the cytoplasmic membrane and loss of culturability $\left(>1500 \mathrm{~kJ} \mathrm{~m}^{-2}\right)$, and finally permeabilization of the membrane $\left(>2000 \mathrm{~kJ} \mathrm{~m}^{-2}\right)$. Also for the highly resistant Salmonella typhimurium, fluences corresponding to about half a day of sunlight $\left(1500 \mathrm{~kJ} \mathrm{~m}^{-2}\right)$ were enough to cause further cellular die-off in the dark (Bosshard et al., 2009). However, the primary

Abbreviations: HPI, HPIl, hydroperoxidase I, II; -P, -phosphate; ROS, reactive oxygen species; SODIS, solar disinfection; TCA, tricarboxylic acid. targets leading to cell death are still unknown. Also, it is not known when the cell crosses the 'point of no return', at which repair is no longer possible and further irreversible cell deterioration occurs in the dark ('dark inactivation'). Therefore, in this work we adressed the questions of what types of damage at the activity level occur during SODIS, and when they accumulate during irradiation.

There is strong evidence that the aerobic energy metabolism of organisms is involved in initial inactivation and also die-off of UVA- and sunlight-irradiated cells (Berney et al., 2006a; Bosshard et al., 2009). Energy metabolism is closely related to integrity of the membrane structure (intact lipid structure, fluidity of the membrane) and functionality of membrane (respiratory chain) proteins. Membranes allow the cells to generate ATP from an electrochemical potential via charge separation. Membrane proteins of the respiratory chain and the ATPase play a vital role in transforming the energy into ATP, a chemical form of energy that is used for many different cellular processes. However, the transport of electrons to the terminal acceptor in the respiratory chain also constitutes a danger for the cell since one-electron carriers are likely to generate reactive oxygen species (ROS) (Gianazza et al., 2007). Many of the respiratory-chain proteins rely on iron as a cofactor, which is a strong Fenton reagent and thus promotes the generation of hydroxyl radicals, the most destructive of 
all ROS. They cause damage to membranes by lipid peroxidation (Niki et al., 2005), but also to membrane proteins, which may be oxidized as a consequence of ROS production (Bourdon \& Blache, 2001). In eukaryotic cells lipid peroxidation induces a chain reaction by degrading polyunsaturated fatty acids into a variety of products, which can be very reactive and are again able to damage proteins (Cabiscol et al., 2000). However, the presence of polyunsaturated lipids is a prerequisite for a peroxidative chain reaction, and most bacterial membranes lack these lipids (Imlay, 2009). Fenton reactions are accelerated by light (so called photo-Fenton reactions), and therefore radical damage speeds up in the light (Chamberlain \& Moss, 1987). In E. coli the damaging effect of UVA light on membranes has been described previously (Moss \& Smith, 1981), and the breakdown of energy metabolism was suggested as a cause for the cellular die-off in this enterobacterium (Berney et al., 2006a; Bosshard et al., 2009). From the present state of knowledge, one can propose several reasons for breakdown of energy-generating systems within an aerobic cell: (a) nutrient uptake is blocked, (b) the generation of reducing equivalents by glycolysis or the tricarboxylic acid (TCA) cycle is blocked, (c) respiration stops, (d) $\mathrm{F}_{1} \mathrm{~F}_{0}$ ATPase is inactivated, or (e) the membrane is depolarized.

In this work, we looked for the primary inactivation mechanisms during SODIS. Likely candidates are types of damage that occur early and affect structures or functions that are vitally important for the cell. Therefore, we focused on the energy-generating systems (respiration and ATP synthase activity) and the physiological response of the cells at the enzyme activity level during the first hour(s) of sunlight irradiation.

\section{METHODS}

Bacterial strains, growth media and cultivation conditions. Wild-type E. coli K-12 MG1655 was used in all experiments. For each experiment, a new tryptic soy agar (TSA; Biolife) plate was loopstreaked from cryo-cultures and incubated at $37^{\circ} \mathrm{C}$ overnight. For batch cultivation, LB broth (10 g tryptone, $5 \mathrm{~g}$ yeast extract, $10 \mathrm{~g}$ $\mathrm{NaCl}$ per litre) was filter-sterilized $(0.2 \mu \mathrm{m})$ and diluted to $1 / 3$ of its original strength. Erlenmeyer flasks containing $20 \mathrm{ml}$ of 1/3-strength LB were loop-inoculated with a single colony and incubated at $37{ }^{\circ} \mathrm{C}$ with vigorous shaking. When the cells reached the exponential growth phase $\left(\mathrm{OD}_{546}\right.$ between 0.1 and 0.2$)$, the culture was diluted to an $\mathrm{OD}_{546}$ of 0.002 into $150 \mathrm{ml}$ prewarmed $\left(37^{\circ} \mathrm{C}\right) 1 / 3$-strength $\mathrm{LB}$ in a $1000 \mathrm{ml}$ Erlenmeyer flask and shaken for $18 \mathrm{~h}$ at $37^{\circ} \mathrm{C}$. By that time the culture had entered stationary phase. Stationary phase was confirmed by five consecutive $\mathrm{OD}_{546}$ measurements within $1 \mathrm{~h}$.

UVA exposure. Cells were harvested by centrifugation $(13000 \mathrm{~g}$ $3 \mathrm{~min}$ ) and washed three times with filter-sterilized bottled water (Evian, France). Depending on the experiment, cells were either diluted with filter-sterilized bottled water to an $\mathrm{OD}_{546}$ of 0.02 and 0.2 (corresponding to approximately $2 \times 10^{7} \mathrm{cells} \mathrm{m}^{-1}$ and $2 \times 10^{8}$ cells $\mathrm{ml}^{-1}$, respectively) or kept at the original $\mathrm{OD}_{546}$ of $2.2\left(\sim 2 \times 10^{9}\right.$ cells $\left.\mathrm{ml}^{-1}\right)$. Cell suspensions were then incubated for $1-2 \mathrm{~h}$ at $37^{\circ} \mathrm{C}$ to allow the cells to adapt to the bottled water. Then aliquots of 10 or $20 \mathrm{ml}$ of cell suspension were exposed to UVA light in $30 \mathrm{ml}$ quartz tubes. The tubes were placed in a carousel reactor (Wegelin et al., 1994) equipped with a medium-pressure mercury lamp (TQ 718) operated at $500 \mathrm{~W}$. The light emitted from the lamp passed through the glass jacket and through a filter solution before reaching the cells in the quartz tubes. The filter solution, consisting of $12.75 \mathrm{~g}$ sodium nitrate $1^{-1}$ (cut-off at $320 \mathrm{~nm}$ ), was used to obtain a UVA light spectrum comparable to solar light. The temperature of the filter solution was maintained at $37{ }^{\circ} \mathrm{C}$ during the experiments. The fluence rates at the position of the tubes were determined for each experiment by chemical actinometry using a volume of 10 or $20 \mathrm{ml}$ (Wegelin et al., 1994). For unirradiated controls, cells were kept in the dark at $37^{\circ} \mathrm{C}$ for the maximum time of UVA exposure. Cells were irradiated at five different fluences in biologically independent triplicates.

Cell fractionation: isolation of membrane vesicles and soluble fraction. Cells were harvested by centrifugation from irradiated and non-irradiated samples (sample volume of $20 \mathrm{ml}$ at a concentration of $1-5 \times 10^{9}$ cells $\mathrm{ml}^{-1}$ ) and disrupted by passage through a precooled French press at 15000 p.s.i. (103.5 MPa) in $3 \mathrm{ml}$ membrane buffer (10 mM MOPS, pH 7.2, $5 \mathrm{mM} \mathrm{MgCl}_{2}, 10 \%$, v/v, glycerol). Unbroken cells were then removed by centrifugation for $15 \mathrm{~min}$ at $16000 \mathrm{~g}$. The remaining supernatant containing the bacterial membranes was spun again for $60 \mathrm{~min}$ at $135000 \mathrm{~g}$ at $4{ }^{\circ} \mathrm{C}$ and the resulting pellet was resuspended in $150 \mu \mathrm{l}$ membrane buffer. Aliquots of $50 \mu \mathrm{l}$ were rapidly frozen in liquid $\mathrm{N}_{2}$ and stored at $-80{ }^{\circ} \mathrm{C}$ (D'Alessandro et al., 2008). The supernatant containing the soluble cell fraction was kept at $-20{ }^{\circ} \mathrm{C}$. The protein content of both membrane and soluble fraction was measured by the method of Bradford (1976).

Enzyme assays for the soluble protein fraction. Enzyme assays were generally based on the spectrophotometric measurement $\left(A_{340}\right)$ of the production or consumption of $\mathrm{NAD}(\mathrm{P}) \mathrm{H}$. Measurement time was 3-5 $\mathrm{min}$, the temperature was kept at $22{ }^{\circ} \mathrm{C}$ and assay volumes were $3 \mathrm{ml}$, containing either 10 or $100 \mu \mathrm{l}$ of soluble protein fraction. Protein concentration of the soluble protein fraction was $2-3 \mathrm{mg}$ $\mathrm{ml}^{-1}$. Background activity was determined in the absence of the substrate. A summary of the composition of the assays is given in Table 1. Malate dehydrogenase (EC 1.1.1.37): $100 \mathrm{mM}$ phosphate buffer $\mathrm{pH} 7.3$ was mixed with freshly prepared NADH $(0.3 \mathrm{mM}$ final concentration) and $10 \mu \mathrm{l}$ of the soluble protein fraction (final protein concentration $6-10 \mu \mathrm{g} \mathrm{ml}^{-1}$ ). The reaction was started with freshly prepared oxalacetic acid ( $0.2 \mathrm{mM}$ final concentration) (Murphey et al., 1969). Glucose-6-P dehydrogenase (EC 1.1.1.49): a buffer containing $55 \mathrm{mM}$ Tris/ $\mathrm{HCl} \mathrm{pH} 7.8$ and $33 \mathrm{mM} \mathrm{MgCl}_{2}$ was amended with NADP $(0.3 \mathrm{mM}$ final concentration) and $100 \mu \mathrm{l}$ of the soluble protein fraction (final protein concentration $60-100 \mu \mathrm{g} \mathrm{ml}^{-1}$ ). The reaction was started with glucose-6-P (3.33 mM final concentration) (John, 2002). Lactate dehydrogenase (EC 1.1.1.27): $100 \mathrm{mM}$ phosphate buffer pH 7.5 was mixed with $\mathrm{NADH}(0.3 \mathrm{mM}$ final concentration), pyruvic acid $(0.2 \%$ final concentration) and $100 \mu \mathrm{l}$ of the soluble protein fraction (final protein concentration 60-100 $\mu \mathrm{g}$ $\mathrm{ml}^{-1}$ ) (Tarmy \& Kaplan, 1968). Glyceraldehyde-3-P dehydrogenase (EC 1.2.1.12): $50 \mathrm{mM}$ phosphate buffer $\mathrm{pH} 8.5$ was mixed with $\mathrm{NAD}^{+}(0.8 \mathrm{mM}$ final concentration), glyceraldehyde-3-P $(0.8 \mathrm{mM}$ final concentration), arsenate ( $5 \mathrm{mM}$ final concentration) and $100 \mu \mathrm{l}$ of the soluble protein fraction (final protein concentration $60-100 \mu \mathrm{g}$ $\mathrm{ml}^{-1}$ ) (Allison \& Kaplan, 1964). Glutathione-disulfide reductase (EC 1.6.4.2): $100 \mathrm{mM}$ HEPES/KOH buffer $\mathrm{pH} 7.8$ was mixed with EDTA ( $1 \mathrm{mM}$ final concentration), NADPH $(0.1 \mathrm{mM}$ final concentration) and $100 \mu \mathrm{l}$ of the soluble protein fraction (final protein concentration $\left.60-100 \mu \mathrm{g} \mathrm{ml}^{-1}\right)$. GSSG ( $1 \mathrm{mM}$ final concentration) was added to start the reaction (Kunert et al., 1990; Anderson et al., 1983).

Enzyme assays for membrane-associated proteins: measurement of respiratory activity by specific substrate-induced oxygen consumption. Enzyme assays for respiratory activity of 
Table 1. Assays for measurement of enzyme activities in the soluble protein fraction

\begin{tabular}{|c|c|c|}
\hline Enzyme $^{\star}$ & Assay composition (final concentrations) & Reference \\
\hline Malate DH & $\begin{array}{l}\text { Phosphate buffer pH } 7.3(100 \mathrm{mM}) \text {; NADH }(0.3 \mathrm{mM}) \text {; oxalacetic acid }(0.2 \mathrm{mM}) \text {; } \\
\text { protein }\left(6-10 \mu \mathrm{g} \mathrm{ml}^{-1}\right)\end{array}$ & Murphey et al. (1969) \\
\hline Glucose-6-P DH & $\begin{array}{l}\text { Tris/HCl pH } 7.8(55 \mathrm{mM}) ; \mathrm{MgCl}_{2}(33 \mathrm{mM}) \text {; NADP }(0.3 \mathrm{mM}) \text {; glucose-6-P } \\
(3.33 \mathrm{mM}) \text {; protein }\left(60-100 \mu \mathrm{ml}^{-1}\right)\end{array}$ & John (2002) \\
\hline Lactate DH & $\begin{array}{l}\text { Phosphate buffer pH } 7.5(100 \mathrm{mM}) \text {; NADH }(0.3 \mathrm{mM}) \text {; pyruvic acid }(0.2 \%) \text {; } \\
\text { protein }\left(60-100 \mu \mathrm{g} \mathrm{ml}^{-1}\right)\end{array}$ & Tarmy \& Kaplan (1968) \\
\hline Glyceraldehyde-3-P DH & $\begin{array}{l}\text { Phosphate buffer pH } 8.5(50 \mathrm{mM}) \text {; } \mathrm{NAD}^{+}(0.8 \mathrm{mM}) \text {; glyceraldehyde-3-P } \\
(0.8 \mathrm{mM}) \text {; arsenate }(5 \mathrm{mM}) \text {; protein }\left(60-100 \mu \mathrm{g} \mathrm{ml}{ }^{-1}\right)\end{array}$ & Allison \& Kaplan (1964) \\
\hline $\begin{array}{l}\text { Glutathione-disulfide } \\
\text { reductase }\end{array}$ & $\begin{array}{l}\text { HEPES/KOH buffer pH } 7.8(100 \mathrm{mM}) \text {; EDTA }(1 \mathrm{mM}) \text {; NADPH }(0.1 \mathrm{mM}) \text {; GSSG } \\
(1 \mathrm{mM}) \text {; protein }\left(60-100 \mu \mathrm{gl}^{-1}\right)\end{array}$ & $\begin{array}{l}\text { Kunert et al. (1990); } \\
\text { Anderson et al. }(1983)\end{array}$ \\
\hline
\end{tabular}

${ }^{\star} \mathrm{DH}$, dehydrogenase.

membranes were performed using assays of $1 \mathrm{ml}$ total volumes in an oxygen electrode (Rank Brothers) in which the oxygen consumption was monitored with different substrates. The enzymes NADHubiquinone oxidoreductase (EC 1.6.5.3), succinate oxidoreductase (EC 1.3.99.1) and L-lactate-cytochrome $c$ oxidoreductase (EC 1.1.2.3) were studied. The assay solution contained $50-150 \mu$ of membrane protein fraction in $50 \mathrm{mM}$ phosphate buffer $\mathrm{pH}$ 7.5. The protein concentration of membrane fractions was $6-8 \mathrm{mg} \mathrm{ml}^{-1}$. Endogenous oxygen consumption was determined before addition of substrate. The initial concentration of the substrate in the assay was $0.3 \mathrm{mM}$ for $\mathrm{NADH}, 1 \mathrm{mM}$ for succinate and $1 \mathrm{mM}$ for lactate.

ATPase activity. A commercial kit was used to evaluate ATPase activity of the membrane fraction (EnzCheck phosphate assay kit, Molecular Probes). The substrate 2-amino-6-mercapto-7-methylpurine riboside (MESG) was used as phosphate scavenger, changing absorption from 330 to $360 \mathrm{~nm}$, which allows quantification of inorganic phosphate $\left(\mathrm{P}_{\mathrm{i}}\right)$ released when ATP is hydrolysed by the $\mathrm{F}_{1} \mathrm{~F}_{0}$ ATPase. The assay solution ( $1 \mathrm{ml}$ in total) contained reaction buffer, MESG substrate, purine nucleoside phosphorylase and membrane protein fraction $(10 \mu \mathrm{l})$. The mixture was preincubated for $10 \mathrm{~min}$ to get rid of background $\mathrm{P}_{\mathrm{i}}$. When a steady baseline was reached, $4 \mu \mathrm{l}$ of $10 \mathrm{mM}$ ATP was added as a substrate for the ATPase and the reaction was followed at $360 \mathrm{~nm}$. To produce a six-point calibration curve, a $\mathrm{P}_{\mathrm{i}}$ standard solution $(500 \mu \mathrm{M})$ was diluted. The protein concentration of membrane fractions was $6-8 \mathrm{mg} \mathrm{ml}^{-1}$. Background $\mathrm{P}_{\mathrm{i}}$ in membrane fractions without addition of ATP was below the detection limit.

Hydroperoxidase assay (HPI and HPII). The two E. coli hydroperoxidases (catalases) are present either as a cytoplasmic membraneassociated enzyme (HPI, kat $G$ gene product) or as a cytosolic enzyme (HPII, katE gene product). Specific activities were measured in wholecell assays. The activity of the two enzymes can be separated by a heat inactivation treatment step because HPII is heat-stable whereas HPI is heat-labile (Visick \& Clarke, 1997). Cells were washed and diluted in PBS to an $\mathrm{OD}_{546}$ of 1.25 and then exposed to UVA irradiation. To measure total catalase activity, prewarmed PBS was mixed with $\mathrm{H}_{2} \mathrm{O}_{2}$ $(0.06 \%$ final $)$ and $0.5 \mathrm{ml}$ cells $\left(\mathrm{OD}_{546} 1.25\right.$ in PBS). Absorption at $240 \mathrm{~nm}$ was measured to follow the rate of decrease of $\mathrm{H}_{2} \mathrm{O}_{2}$. The assay volume was $3 \mathrm{ml}$ and temperature was kept at $37^{\circ} \mathrm{C}$. To measure activity of HPI alone, HPII was inactivated prior to analysis at $55{ }^{\circ} \mathrm{C}$ for $15 \mathrm{~min}$.

ATP-generation potential. Cell suspensions $\left(900 \mu\right.$ l, containing $10^{7}$ cells $\mathrm{ml}^{-1}$ ) were incubated either with $100 \mu \mathrm{l}$ prewarmed autoclaved full-strength LB or with $100 \mu \mathrm{l}$ bottled water (as a control) at $37{ }^{\circ} \mathrm{C}$ for $1,5,10,20$ or $40 \mathrm{~min}$. The ability of the cells to produce ATP from the substrate was tested by measuring total ATP immediately after the incubation with the BacTiterGlo System (Promega) as described previously (Bosshard et al., 2009). The immediate response after $1 \mathrm{~min}$ is very fast and becomes linear only after the first $5 \mathrm{~min}$ of incubation ('steady state'). Therefore, only ATP levels after 5, 10, 20 and $40 \mathrm{~min}$ were considered for calculating the ATP production rate, or ATP-generation potential, and those data were used for the calculation of a linear regression curve $(\Delta \mathrm{ATP} / \Delta t)$. It was not necessary to distinguish between 'free' and 'cellular' ATP as fractions of 'total' ATP (Hammes et al., 2008) since initial experiments showed that total ATP corresponded to intracellular ATP for our experimental settings and free ATP was found only as a negligible fraction $(<5 \%)$. In all experiments no changes in $\mathrm{OD}_{546}$ were observed.

(Photo)stability of ATP. ATP was diluted to $10 \mathrm{nM}$ in bottled water and immediately filter-sterilized. Samples of $10 \mathrm{ml}$ were irradiated and the ATP content of the samples was measured with the BacTiterGlo System immediately after sampling. A slight degradation of ATP with time was observed. However, the degradation rate did not affect the ATP degradation experiments performed (discussed later).

Plating. Aliquots were withdrawn at different time points during irradiation and during subsequent dark storage and diluted in decimal steps $\left(10^{-1}\right.$ to $\left.10^{-5}\right)$ with sterile-filtered bottled water. Following dilution, $1 \mathrm{ml}$ test solution was withdrawn and mixed with $7 \mathrm{ml}$ TSA (Biolife) at $40{ }^{\circ} \mathrm{C}$ (pour plate method). After $20 \mathrm{~min}$, the solidified agar was covered with another $4 \mathrm{ml}$ of liquid TSA $\left(40{ }^{\circ} \mathrm{C}\right)$. Plates were incubated for $48 \mathrm{~h}$ at $37{ }^{\circ} \mathrm{C}$ until further analysis. Plate counts were determined with an automatic plate reader (acolyte, SYNBIOSIS).

\section{RESULTS}

\section{ATP-generation potential of cells when adding substrate after irradiation}

To exclude the possibility of non-biological ATP degradation during irradiation experiments, degradation of pure ATP was measured in sterile-filtered bottled water without addition of bacterial cells. Only slight degradation of pure ATP in bottled water was observed from exposure to UVA light compared to dark controls $(<12 \%)$. This degradation 
might have been caused by small microbial cells present in virtually all waters that are not retained by $0.2 \mu \mathrm{m}$ poresize filters (Wang et al., 2007); however, particularly in the initial phase of the experiments, the results were not affected by this slight degradation of ATP (see Methods). The ATP content of E. coli cells showed an initial transient increase to $110 \%$ of the initial value and then dropped massively with increasing UVA fluence (Fig. 1). This suggests that low light stress activates cells and induces ATP generation to enable repair of damage. A similar increase of total ATP in cells exposed to low fluences was found in Salmonella typhimurium by Bosshard et al. (2009).

The ability to produce ATP is of vital importance for survival of cells during UVA irradiation. Therefore, we measured this ability in a whole-cell assay where the cells were supplied with nutrients and the ATP production rate was determined. This represents a whole-cell ATPgeneration potential. To provide nutrients, LB diluted to $10 \%$ of its original strength was added. When added to non-irradiated cells, the substrate was converted over 40 min to a level of $180 \times 10^{-7}$ ng ATP per cell. This capacity was reduced to one-third even at a fluence of $180 \mathrm{~kJ} \mathrm{~m}^{-2}$, and for fluences higher than this it decreased further, reaching a residual level as low as $20 \times 10^{-7} \mathrm{ng}$ ATP per cell at a fluence of $900 \mathrm{~kJ} \mathrm{~m}^{-2}$ (Fig. 2). Moreover, when doses higher than $180 \mathrm{~kJ} \mathrm{~m}^{-2}$ were applied, the production of ATP after addition of substrate was already exhausted after $5 \mathrm{~min}$ and the ATP content remained constant.

The ATP-generation potential of the cells was massively reduced to about $15 \%$ for a UVA exposure of $180 \mathrm{~kJ} \mathrm{~m}^{-2}$ and then, with fluences up to $900 \mathrm{~kJ} \mathrm{~m}^{-2}$, dropped to $3 \%$

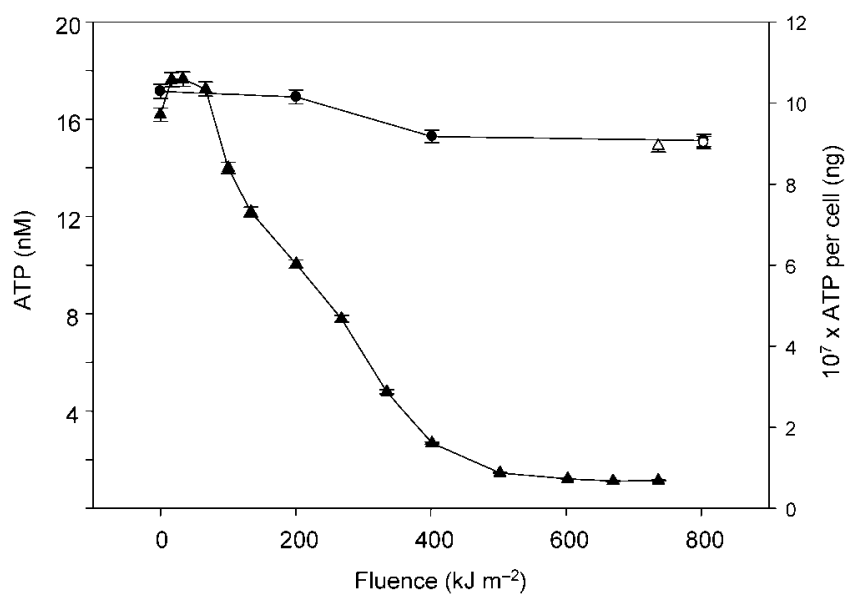

Fig. 1. Photostability of ATP in sterile-filtered bottled water ( $\bullet$ left axis) and of cellular ATP content in E. coli during UVA irradiation in sterile-filtered bottled water ( $\boldsymbol{\Lambda}$, right axis). Dark controls are represented by empty symbols. Means \pm SE $(n=3)$ are plotted.

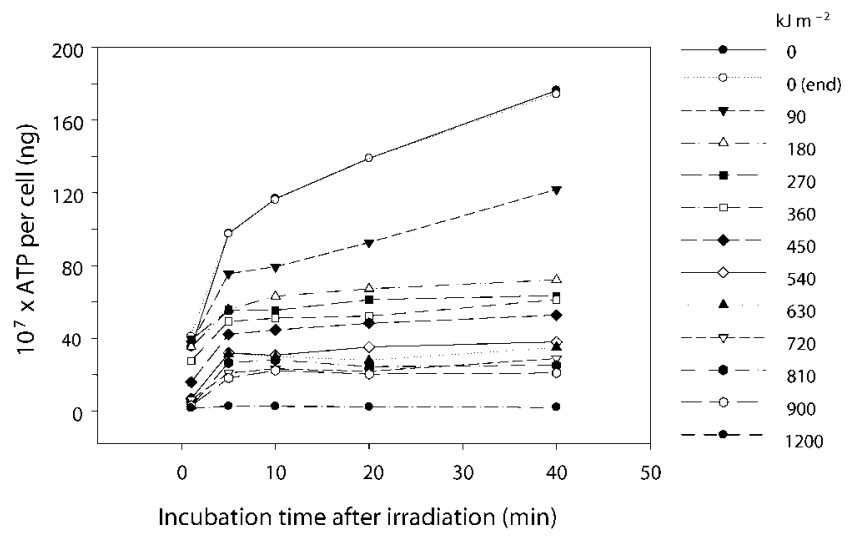

Fig. 2. ATP levels of cells first exposed to a defined UVA fluence and then immediately incubated in $10 \%$ LB medium (final concentration) for 1, 5, 10, 20 and $40 \mathrm{~min}$. An unirradiated control $\left(0 \mathrm{~kJ} \mathrm{~m}^{-2}\right)$ was measured at the beginning and at the end of the experimental period.

and below (Table 2). Without addition of substrate, the ATP-regenerating activity was always very low in irradiated samples $(<2 \%$ of unirradiated control). An initial increase in ATP regeneration up to $20 \times 10^{-7}$ ng ATP per cell was observed within the first $5 \mathrm{~min}$ of the assay for fluences between 180 and $900 \mathrm{~kJ} \mathrm{~m}^{-2}$ (Fig. 2). Therefore, for calculation of the ATP-regenerating activity only the data points between 5 and 40 min of incubation were included in the linear regression curve. When applying higher fluences $\left(>1200 \mathrm{~kJ} \mathrm{~m}^{-2}\right)$ this initial ATP boost decreased massively.

\section{Enzymes of the inner membrane and hydroperoxidases}

In order to achieve a high enough concentration of proteins for enzyme activity assays, $10^{9}$ cells $\mathrm{ml}^{-1}$ were irradiated. Culturability of the cells decreased by about one $\log$ for a fluence of $900 \mathrm{~kJ} \mathrm{~m}^{-2}$ or by 7 logs for a fluence of $2000 \mathrm{~kJ} \mathrm{~m}^{-2}$ (Fig. 3a). Hence, both shoulder length and degree of inactivation were similar to those achieved at lower cell densities, e.g. $10^{7}$ cells $\mathrm{ml}^{-1}$, indicating no significant effect of shading. All three respiratory-chain enzymes assessed completely lost their activity very early in the irradiation process at $50-100 \mathrm{~kJ} \mathrm{~m}^{-2}$ (Fig. 3b), a fluence that corresponds to only $6-10 \mathrm{~min}$ of natural sunlight exposure. $\mathrm{F}_{1} \mathrm{~F}_{0}$ ATPase activity decreased exponentially between 0 and $1000 \mathrm{~kJ} \mathrm{~m}^{-2}$ (Fig. 3c); it appears to be slightly less sensitive than the ATP generation potential described above. Both hydroperoxidases dropped massively in activity with fluences up to $300 \mathrm{~kJ} \mathrm{~m}^{-2}$ (Fig. 4). Membrane-bound HPI lost its activity completely during the first $600 \mathrm{~kJ} \mathrm{~m}^{-2}$, whereas the cytosolic HPII maintained some residual activity amounting to $5-10 \%$ of the unirradiated control. 
Table 2. ATP-generation potential of UVA-irradiated E. coli cells with addition of substrate (LB, $10 \%$ final concentration) within 40 min after the addition of substrate

Details of calculations are given in the text.

\begin{tabular}{|c|c|c|c|c|c|c|}
\hline \multirow[t]{2}{*}{ Fluence $\left(k J \mathbf{m}^{-2}\right)$} & \multicolumn{3}{|c|}{ With nutrients $(10 \% \mathrm{LB})$} & \multicolumn{3}{|c|}{ Control without nutrient supply } \\
\hline & $\Delta \mathrm{ATP} / \Delta t\left(\mathrm{nM} \min ^{-1}\right)$ & $\Delta \mathrm{ATP} /\left(\Delta t \times \mathrm{OD}_{546}\right)$ & $\%$ & $\Delta \mathrm{ATP} / \Delta t\left(\mathrm{nM} \min ^{-1}\right)$ & $\Delta \mathrm{ATP} /\left(\Delta t \times \mathrm{OD}_{546}\right)$ & $\%$ \\
\hline 0 & 3.59 & 17.958 & 100.00 & 0.21 & 1.027 & 5.72 \\
\hline 0 (dark control) & 3.68 & 18.4015 & 102.47 & 0.15 & 0.75 & 4.18 \\
\hline 90 & 2.30 & 11.5075 & 64.08 & 0.03 & 0.15 & 0.84 \\
\hline 180 & 0.42 & 2.08 & 11.58 & 0.03 & 0.1315 & 0.73 \\
\hline 270 & 0.70 & 3.5105 & 19.55 & 0.05 & 0.2315 & 1.29 \\
\hline 360 & 0.42 & 2.08 & 11.58 & 0.06 & 0.2975 & 1.66 \\
\hline 450 & 0.57 & 2.838 & 15.80 & 0.02 & 0.115 & 0.64 \\
\hline 540 & 0.50 & 2.504 & 13.94 & 0.01 & 0.0325 & 0.18 \\
\hline 630 & 0.34 & 1.7225 & 9.59 & 0.02 & 0.083 & 0.46 \\
\hline 720 & 0.21 & 1.067 & 5.94 & 0.01 & 0.0365 & 0.20 \\
\hline 810 & 0.11 & 0.559 & 3.11 & 0.01 & 0.0365 & 0.20 \\
\hline 900 & 0.06 & 0.3155 & 1.76 & 0.01 & 0.0645 & 0.36 \\
\hline 1120 & 0.00 & 0.0105 & 0.06 & 0.01 & 0.0505 & 0.28 \\
\hline
\end{tabular}
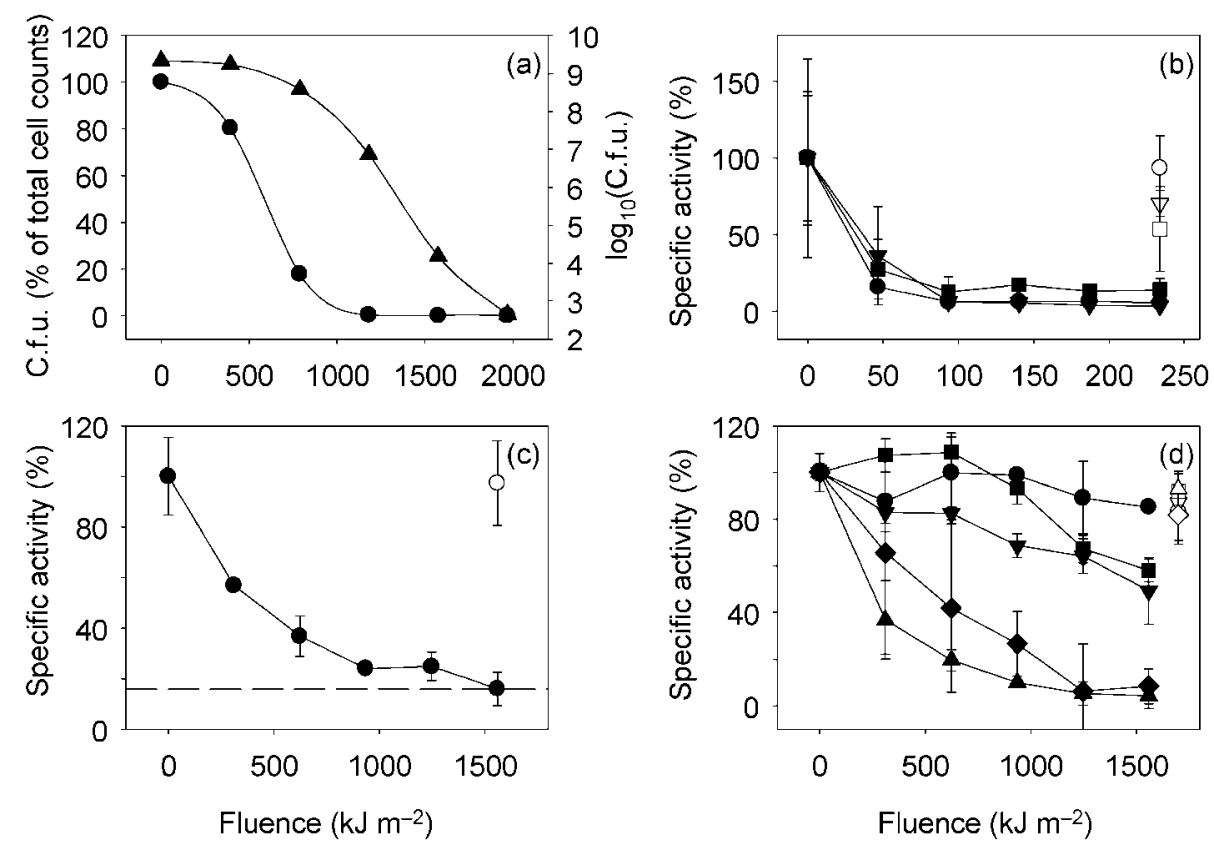

Fig. 3. Culturability and specific enzyme activities in UVA-irradiated E. coli cells. The cell suspensions irradiated had a density of $10^{9}$ cells $\mathrm{ml}^{-1}$ and activities are depicted as a percentage of the activity found in untreated cells. (a) Culturability shown as a

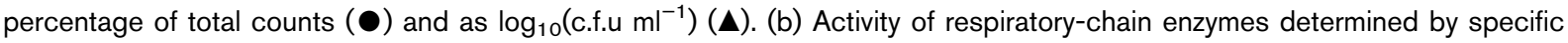
substrate-induced oxygen consumption in the membrane fraction: NADH oxidase $(\boldsymbol{\bullet})$, succinate oxidase $(\boldsymbol{\nabla})$, lactate oxidase (西 $\left[100 \%\right.$ corresponds to $4.75,4.68$ and $0.63 \mathrm{mg} \mathrm{O}_{2} \min ^{-1}$ (mg protein) ${ }^{-1} \mathrm{ml}^{-1}$, respectively]. (c) $\mathrm{F}_{1} \mathrm{~F}_{0}$-ATPase activity in the membrane fraction [100\% corresponds to $47.52 \mu \mathrm{M} \mathrm{P}_{\mathrm{i}} \min ^{-1}$ (mg protein) ${ }^{-1} \mathrm{ml}^{-1}$ ]. The dashed line shows background activity of the membrane fraction with the $F_{1} F_{0}$-ATPase-specific inhibitor dicyclohexylcarbodiimide (DCCD). (d) Activity of enzymes in the cytoplasm: malate dehydrogenase $(\boldsymbol{\bullet})$, lactate dehydrogenase $(\boldsymbol{\square})$, glucose-6-P dehydrogenase $(\boldsymbol{\nabla})$, glutathione-disulfide reductase $(\boldsymbol{})$, glyceraldehyde-3-P dehydrogenase $(\boldsymbol{\Lambda})$ [100\% corresponds to a specific activity in $\mu \mathrm{mol}(\mathrm{mg} \mathrm{protein})^{-1} \mathrm{~min}^{-1}$ of $0.406,0.045,0.375,0.0198$ and 0.0177 , respectively]. Empty symbols represent dark controls. Means \pm SE $(n=3)$ are plotted in $(b-d)$. 


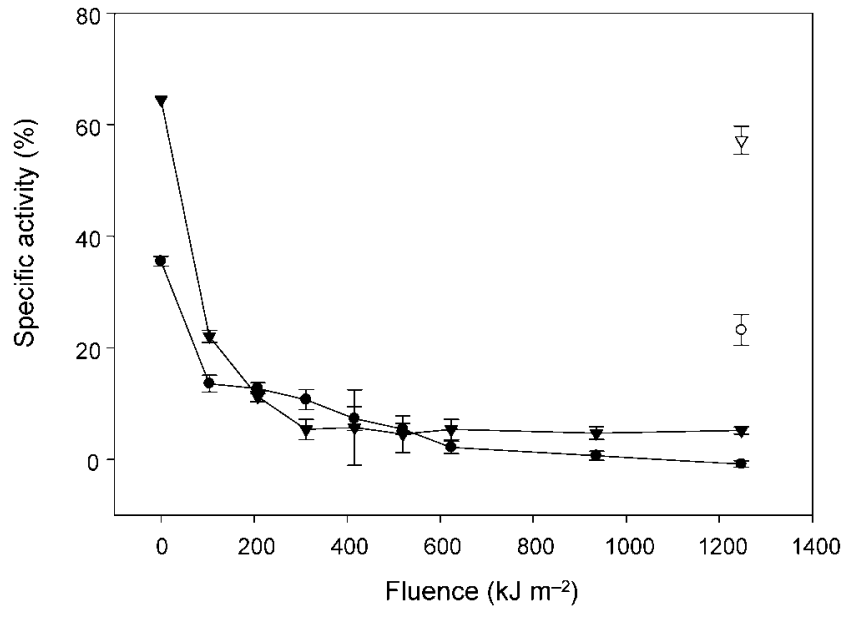

Fig. 4. Specific activities of hydroperoxidases $\left[\Delta A_{240}\right]$ $\left.\left(\min \times \Delta \mathrm{OD}_{546}\right)\right]$ : HPI $(\boldsymbol{O})$, HPII $(\boldsymbol{\nabla})[100 \%$ corresponds to $0.0173 \Delta A_{240} \Delta \mathrm{OD}_{546}{ }^{-1} \mathrm{~min}^{-1}$ ]. Empty symbols represent dark controls. Means \pm SE $(n=3)$ are plotted.

\section{Enzymes of the cytoplasm}

With the notable exception of HPII, cytosolic enzymes generally maintained their activity longer than enzymes in membranes (Fig. 3d). Malate dehydrogenase activity was almost unaffected by irradiation up to a fluence of $1600 \mathrm{~kJ}$ $\mathrm{m}^{-2}$; lactate dehydrogenase and glucose-6-P dehydrogenase activity were reduced only to about $50 \%$. Glutathione reductase and glyceraldehyde-3-P dehydrogenase lost their activity completely after a fluence of $1250 \mathrm{~kJ} \mathrm{~m}^{-2}(<1 \%)$. This is consistent with a previous study on glyceraldehyde3-P dehydrogenase, where a reduction to $10 \%$ of the initial activity was found with an applied UVA fluence of $1000 \mathrm{~kJ}$ $\mathrm{m}^{-2}$ (Voss et al., 2007).

\section{Dark inactivation after UVA irradiation}

In an earlier study we reported that dark storage after half a day of sunlight exposure $\left(1500 \mathrm{~kJ} \mathrm{~m}^{-2}\right)$ progressively killed not only E. coli, but also Salmonella typhimurium, a bacterium that is less susceptible to sunlight than other enteropathogens (Bosshard et al., 2009). To study this process of dark inactivation in more detail and to obtain a better time resolution, E. coli was used here as a model organism. The cells were irradiated in the lower fluence range to elucidate whether a threshold fluence exists, at which the cell is damaged only reversibly and where it is still able to recover and repair the damage accumulated during irradiation. Cells irradiated with UVA up to $150 \mathrm{~kJ} \mathrm{~m}^{-2}$ (50, $100,150 \mathrm{~kJ} \mathrm{~m}^{-2}$ were tested) and subsequently stored in the dark for up to $48 \mathrm{~h}$ showed no effect and behaved like the unirradiated control. At higher doses, a massive drop in culturability of one $\log$ (after $300,480 \mathrm{~kJ} \mathrm{~m}^{-2}$ ), two to three $\operatorname{logs}$ (after $950,1500 \mathrm{~kJ} \mathrm{~m}^{-2}$ ) or close to the detection limit (after $1900 \mathrm{~kJ} \mathrm{~m}^{-2}$ ) was observed (Fig. 5). These results

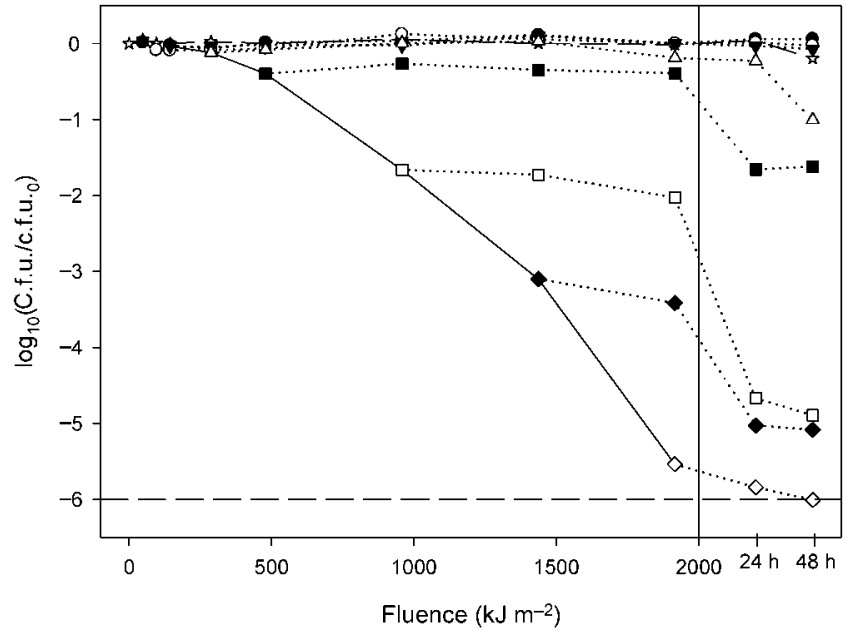

Fig. 5. Irradiation and subsequent dark storage of UVA-irradiated E. coli cells. Cells were exposed at a density of $10^{7}$ cells $\mathrm{ml}^{-1}$ to fluences of $50(\bullet), 100(\bigcirc), 150(\nabla), 300(\triangle), 480(\square), 950(\square)$, $1500(\diamond)$ and $1900 \mathrm{~kJ} \mathrm{~m}^{-2}(\diamond)$ during the first $7 \mathrm{~h}$ of the experiment and stored in the dark thereafter (indicated by the dotted lines). A non-irradiated control is also shown (star symbol). At $t_{24}$ and $t_{48}$ after the start of the experiment, samples were plated again to determine the degree of survival (panel on the right, for 24 and $48 \mathrm{~h}$ of storing in the dark). The experiment was repeated three times; representative results are shown. The dashed line represents the detection limit.

demonstrate that after a fluence of approximately $300 \mathrm{~kJ}$ $\mathrm{m}^{-2}$ no or insufficient repair occurred to allow recovery.

\section{DISCUSSION}

\section{Changes in cellular energy metabolism during UVA irradiation}

The temporal inactivation pattern of different cellular functions during SODIS is illustrated in a conceptual graph in Fig. 6. The breakdown of respiration precedes all other tested crucial cellular functions such as the massive decrease in catalase activity, the depletion of the cellular ATP pool, and the loss of ATPase activity and culturability. Membrane depolarization and permeabilization were observed only later in the inactivation process, an observation previously reported by Berney et al. (2006a). Therefore, special emphasis is given to the loss of essential cellular processes of energy generation, a subject that will be discussed in more detail below.

A cell's ability to maintain its ATP level is essential for coping with any stress situation where it needs readily available energy for defence and repair of damage. A decrease in the ATP-generation potential is therefore fatal for a cell under stress. For this reason, we assessed the cell's immediate response to restore cellular energy (ATP) in the presence of nutrients. To our knowledge, this is a new 


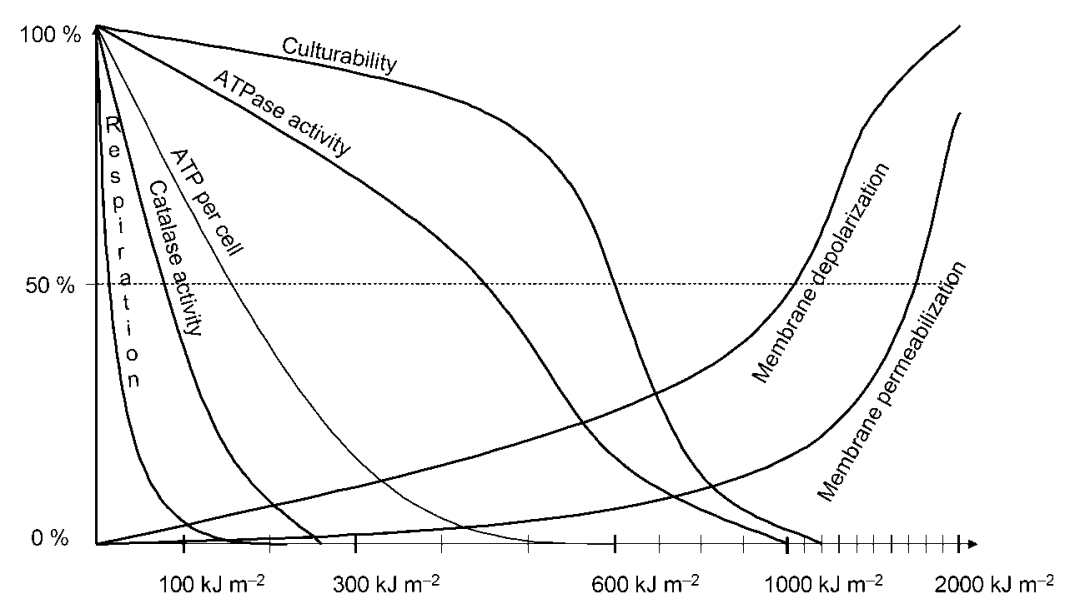

Fig. 6. Conceptual graph showing the temporal pattern of inactivation by UVA light in stationary-phase $E$. coli cells. Catalase activity represents the combined activity of $\mathrm{HPI}$ and HPII. Values for membrane depolarization and permeabilization are taken from Berney et al. (2006a). One tick corresponds to a fluence of $100 \mathrm{~kJ} \mathrm{~m}^{-2}$. approach to evaluating cellular viability. Even at an exposure as low as $180 \mathrm{~kJ} \mathrm{~m}^{-2}$, corresponding to less than half an hour of sunlight, the cells were massively affected in their ability to immediately produce ATP (Fig. 2, Table 1). However, if incubated on agar plates, more than $90 \%$ of the cells were still able to repair their damage and to produce a colony after exposure to such low fluences (Fig. 3a). In contrast, the ability to produce ATP was virtually non-existent when cells were irradiated with fluences of approximately $1200 \mathrm{~kJ} \mathrm{~m} \mathrm{~m}^{-2}$ (Fig. 2), an irradiation level at which culturablity on agar plates dropped to $<1 \%$ (Fig. 3a). These observations might be explained by a breakdown of energy metabolism during UVA irradiation in three phases. Initially, the cells were probably still able to transport substrates and link this to ATP production, which corresponds to the phase where an initial ATP increase at fluences below $180 \mathrm{~kJ} \mathrm{~m}^{-2}$ was observed (Fig. 1). Secondly, at fluences exceeding $180 \mathrm{~kJ}$ $\mathrm{m}^{-2}$, the cells still had a residual capacity to produce ATP and recharge their cellular ATP pool to a level in the range of $20 \times 10^{-7}$ ng ATP per cell (Fig. 2). In this phase, the processes that use ATP were possibly still slower than those that resynthesize it. ATP was probably employed in this phase for restoration of the membrane potential, which was maintained up to fluences of $1000 \mathrm{~kJ} \mathrm{~m}^{-2}$ at levels $>50 \%$ of its original value (Fig. 6), and maybe some of the generated ATP was also used for repair processes. In the third phase, at fluences higher than $1200 \mathrm{~kJ} \mathrm{~m}^{-2}$, the cells had lost the capacity to restore their cellular ATP pool; now ATPase activity dropped massively and also the membrane started to become leaky, as measured in an earlier study by live/dead-staining (Berney et al., 2006a). After an initial shoulder where colony formation was affected only slightly (Berney et al., 2006b), culturability decreased exponentially at fluences higher than $900 \mathrm{~kJ} \mathrm{~m}^{-2}$. This suggests that a cell tries to maintain as long as possible the membrane potential, which is important for many of the substrate transport processes across the membrane, via ATPase.

The finding that cells lose their ability to regenerate ATP has to be interpreted with caution because several
ATP-consuming and -producing metabolic processes influence the pool. The ATP pool is subject to turnover and we measured neither the turnover rate nor the single processes that use or generate ATP separately. Processes involved in ATP consumption include uptake of nutrients by membrane-transport systems, repair and restoration of membrane potential; processes involved in ATP generation are oxidative phosphorylation and substrate-level phosphorylation. Contributions of individual ATP-consuming processes are difficult to measure, and therefore were not investigated here. To get a rough idea of the underlying processes, we focused on investigating individual components and enzymes involved in the generation of ATP: oxidative phosphorylation via $\mathrm{F}_{1} \mathrm{~F}_{0}$ ATPase, glycolysis (represented by glyceraldehyde-3-P dehydrogenase), the TCA cycle (represented by malate dehydrogenase) and respiration (represented by $\mathrm{NADH}$ oxidase, succinate oxidase and lactate oxidase activity of the cytoplasmic membrane). Evidently, nutrient uptake is an essential prerequisite that fuels all of these processes with electron donors.

Respiratory membrane enzymes were targeted very early during irradiation. The functioning of the respiratory chain is essential for aerobic cells since it is, together with $\mathrm{F}_{1} \mathrm{~F}_{0}$ ATPase, the most efficient way to produce a membrane potential and ATP. Many of these enzymes, such as NADH dehydrogenase and succinate dehydrogenase, contain Fe-S centres; cytochromes contain haems and Fe-S centres. In E. coli, all the dehydrogenases tested translocate electrons to a central ubiquinone/ubiquinol pool in the membrane, which then gets oxidized by either cytochrome $b o_{3}$ (a haem-copper protein with low oxygen affinity, which is specifically expressed at high $\mathrm{O}_{2}$ saturation levels and is therefore relevant for our cells), or cytochrome $b d$ (expressed when oxygen is limiting and containing 2 $b$-type haems as acceptors and a $d$-type haem as oxygenreduction site, both with high oxygen affinity) (Nicholls \& Ferguson, 1992; Unden \& Dünnwald, 2008). The fact that all the dehydrogenases are inactivated at similar fluences suggests that each of these enzymes is not inactivated 
independently, but that the electron-transport chain is interrupted.

The ability to take up nutrients is essential for the cell's survival. The ability to take up a fluorescent glucose analogue was tested in earlier studies, which showed that this function remained active even up to higher fluences than the ATPase (Berney et al., 2006a; Bosshard et al., 2009). The reason for this is probably that this analogue is transported by the phosphotransferase system, which is fed with energy via substrate-level phosphorylation. Different studies have shown that near-UV affects the uptake of amino acids into the cell (Ascenzi \& Jagger, 1979; Robb et al., 1978; Sharma \& Jagger, 1981). Preliminary results from Biolog-AN plates (data not shown) indicated that not only uptake and oxidation of amino acids, but also the ability to transport and oxidize many other compounds was reduced early during irradiation. The ability to reduce substrates in the assay was lost simultaneously for all C-sources, again indicating that the final step of the respiratory chain is inactivated at this time rather than single transport systems within the membrane (Bochner, 2009).

The cytoplasmic metabolic enzymes of glycolysis and most enzymes of the TCA cycle are part of the soluble fraction of the cell. These remained active up to considerably higher fluences than membrane enzymes. Generally, the susceptibility of the soluble enzymes tested varied over a wide range. In contrast to membrane enzmyes, none of those tested here have metal cofactors. Lactate and malate dehydrogenases also exhibited a high resistance to ozone treatment in an earlier study (Komanapalli et al., 1997), which corresponds to the relatively high UVA resistance in our experiments. In contrast, glyceraldehyde-3-P dehydrogenase lost most of its activity during ozone treatment, as it did during UVA treatment here.

\section{Cellular defence against ROS during UVA irradiation}

Hydroperoxidases and glutathione-disulfide reductase are part of the ROS defence system of the cell. Glutathionedisulfide reductase activity was kept up for a relatively long time during UVA irradiation compared, for example, to enzymes of the respiratory chain. This enzyme was found to be quite resistant to UVA and ozone treatment in previous studies (Hoerter et al., 2005; Komanapalli et al., 1997). In contrast, both HPI and HPII were rapidly inactivated in our experiments. Both types of hydroperoxidases contain a haem cofactor (Claiborne \& Fridovich, 1979; Claiborne et al., 1979). These iron centres are probable ROS generators, and this may explain the fast inactivation of the two HP enzymes in UVA light. In addition, our results show that the membrane-associated and heat-labile HPI lost its activity even earlier than the cytoplasmic HPII. The higher heat resistance of HPII was argued to be a result of stabilizing elements in the structure and the presence of haem $d$ instead of haem $b$ (Switala \&
Loewen, 2002). These factors may explain the higher resistance of HPII to UVA light as well.

\section{Inactivation in the dark after irradiation}

The breakdown of enzymic processes observed here must reach a point where the cell becomes unable to repair the damage and, as a consequence of energy limitation, the cell will be damaged lethally. We were interested in the 'point of no return', where irreversible cell damage had occurred. Therefore, cells were irradiated with relatively low UVA fluences and subsequently stored in the dark. It was assumed that irreversibly damaged cells would continue dying when stored in the dark, while reversibly damaged cells would be able to repair their damage as soon as they were plated and obtained nutrients. A threshold fluence for irreversible damage was indeed observed: at fluences below $300 \mathrm{~kJ} \mathrm{~m}^{-2}$ the cells were able to recover from UVA damage. At higher fluences, even if the inactivation process was still in the 'shoulder' phase (extending up to $900 \mathrm{~kJ}$ $\mathrm{m}^{-2}$ ), where repair should theoretically be possible (Harm, 1980), they progressively lost culturability in the dark when irradiation was stopped. Even when supplied with nutrients the cells were unable to refill their ATP pool since the regeneration capacity itself was damaged, as shown above. In practice this implies that cells should not recover from UVA light damage, even after short irradiation times, or lower fluences due to overcast conditions, or increased water turbidity.

\section{ROS-mediated damage to membrane proteins probably causes cell death during SODIS}

Our results corroborate the inactivation mechanism proposed previously (Bosshard et al., 2009), which comprises an early inhibition of the respiratory chain and the ability to maintain the membrane potential by reversed action of the ATP synthase. Indeed, ATPase activity dropped at the same time as the membrane potential collapsed, as measured by $\mathrm{DiBAC}_{4}(3)$ staining (Berney et al., 2006a). Therefore, we can conclude with some certainty that membrane proteins are the first targets during SODIS. Already after applying a fluence of only $50 \mathrm{~kJ} \mathrm{~m}^{-2}$, activity of respiratory-chain enzymes in the membranes was reduced, and for fluences $>300 \mathrm{~kJ} \mathrm{~m}^{-2}$ cell damage definitely became irreversible. In the cell, the respiratory chain is responsible for some $90 \%$ of the $\mathrm{OH}^{\bullet}$ radical production under normal growth conditions (Gonzalez-Flecha \& Demple, 1995). $\mathrm{OH}^{\bullet}$ radicals are short-lived, and react close to where they are produced (Latch \& McNeill, 2006). This implies that membrane proteins (respiratory enzymes, $\mathrm{F}_{1} \mathrm{~F}_{0}$ ATPase) and lipids are especially in danger of oxidation by this species, as also assumed by other authors (Choksi et al., 2008). One could argue that with an interrupted respiratory chain the electron flow and thereby also ROS stress would immediately be stopped. However, when considering for example the still increasing protein oxidation levels with fluences 
$>50 \mathrm{~kJ} \mathrm{~m}^{-2}$ (Bosshard et al., 2010), it seems clear that some form of oxidative stress continues after inhibition of respiration. The continuing ROS production with a nonfunctional respiratory chain might result from a still-active electron-transport chain that continues to produce ROS by dumping electrons in the surroundings instead of providing a controlled delivery to the terminal acceptor. Another possibility is that in the presence of a non-functional respiratory chain, reducing agents are accumulated within the cell and drive ROS production by metal-catalysed oxidation reactions. Such reactions are known to be fuelled within the cell by reduced $\mathrm{NAD}(\mathrm{P}) \mathrm{H}$ in the presence of oxygen and iron. The reducing equivalents thereby produced are used to regenerate the metal (Levine, 2002). A third possibility is that an increased ratio of TCA cycle to respiratory activity boosts the production of ROS, a common mode of action observed with many antibiotics (Kohanski et al., 2007). DNA damage was observed during near-UV irradiation also (Jiang et al., 2009), but only after irradiation at relatively high fluences $\left(>800 \mathrm{~kJ} \mathrm{~m}^{-2}\right)$. Therefore, protein damage must be considered to be an early and essential target during SODIS cell inactivation.

\section{ACKNOWLEDGEMENTS}

This project was financially supported by the Velux Foundation (project Nr. 346). We thank Frédéric Gabriel for practical help with the oxygen electrode and Frederik Hammes for valuable discussions concerning ATP measurement.

\section{REFERENCES}

Allison, W. S. \& Kaplan, N. O. (1964). The comparative enzymology of triosephosphate dehydrogenase. J Biol Chem 239, 2140-2152.

Anderson, J. W., Foyer, C. H. \& Walker, D. A. (1983). Light-dependent reduction of dehydroascorbate and uptake of exogenous ascorbate by spinach chloroplasts. Planta 158, 442-450.

Ascenzi, J. M. \& Jagger, J. (1979). Ultraviolet action spectrum (238$405 \mathrm{~nm}$ ) for inhibition of glycine uptake in E. coli. Photochem Photobiol 30, 661-666.

Berney, M., Weilenmann, H.-U. \& Egli, T. (2006a). Flow-cytometric study of vital cellular functions in Escherichia coli during solar disinfection (SODIS). Microbiology 152, 1719-1729.

Berney, M., Weilenmann, H. U., Simonetti, A. \& Egli, T. (2006b). Efficacy of solar disinfection of Escherichia coli, Shigella flexneri, Salmonella Typhimurium and Vibrio cholerae. J Appl Microbiol 101, 828-836.

Bochner, B. R. (2009). Global phenotypic characterization of bacteria. FEMS Microbiol Rev 33, 191-205.

Bosshard, F., Berney, M., Scheifele, M., Weilenmann, H.-U. \& Egli, T. (2009). Solar disinfection (SODIS) and subsequent dark storage of Salmonella typhimurium and Shigella flexneri monitored by flow cytometry. Microbiology 155, 1310-1317.

Bosshard, F., Riedel, K., Schneider, T., Geiser, C., Bucheli, M. \& Egli, T. (2010). Protein oxidation and aggregation in UVA-irradiated Escherichia coli cells as signs of accelerated cellular senescence. Environ Microbiol (in press) doi:10.1111/j.1462-2920.2010.02268.x.

Bourdon, E. \& Blache, D. (2001). The importance of proteins in defence against oxidation. Antioxid Redox Signal 3, 293-311.
Bradford, M. M. (1976). A rapid and sensitive method for the quantitation of microgram quantities of protein utilizing the principle of protein-dye binding. Anal Biochem 72, 248-254.

Cabiscol, E., Tamarit, J. \& Ros, J. (2000). Oxidative stress in bacteria and protein damage by reactive oxygen species. Int Microbiol 3, $3-8$.

Chamberlain, J. \& Moss, S. H. (1987). Lipid peroxidation and other membrane damage produced in Escherichia coli K1060 by near-UV radiation and deuterium oxide. Photochem Photobiol 45, 625-630.

Choksi, K. B., Nuss, J. E., DeFord, J. H. \& Papaconstantinou, J. (2008). Age-related alterations in oxidatively damaged proteins of mouse skeletal muscle mitochondrial electron transport chain complexes. Free Radic Biol Med 45, 826-838.

Claiborne, A. \& Fridovich, I. (1979). Purification of the $o$-dianisidine peroxidase from Escherichia coli B. Physicochemical characterization and analysis of its dual catalatic and peroxidatic activities. J Biol Chem 254, 4245-4252.

Claiborne, A., Malinowski, D. P. \& Fridovich, I. (1979). Purification and characterization of hydroperoxidase II of Escherichia coli B. J Biol Chem 254, 11664-11668.

Conroy, R. M., Meegan, M. E., Joyce, T., McGuigan, K. \& Barnes, J. (2001). Solar disinfection of drinking water protects against cholera in children under 6 years of age. Arch Dis Child 85, 293-295.

D’Alessandro, M., Turina, P. \& Melandri, B. A. (2008). Intrinsic uncoupling in the ATP synthase of Escherichia coli. Biochim Biophys Acta 1777, 1518-1527.

Gianazza, E., Crawford, J. \& Miller, I. (2007). Detecting oxidative post-translational modifications in proteins. Amino Acids 33, 51-56.

Gonzalez-Flecha, B. \& Demple, B. (1995). Metabolic sources of hydrogen peroxide in aerobically growing Escherichia coli. J Biol Chem 270, 13681-13687.

Hammes, F., Berney, M., Wang, Y., Vital, M., Koster, O. \& Egli, T. (2008). Flow-cytometric total bacterial cell counts as a descriptive microbiological parameter for drinking water treatment processes. Water Res 42, 269-277.

Harm, W. (1980). Biological Effects of Ultraviolet Radiation. Cambridge: Cambridge University Press.

Hoerter, J. D., Arnold, A. A., Kuczynska, D. A., Shibuya, A., Ward, C. S., Sauer, M. G., Gizachew, A., Hotchkiss, T. M., Fleming, T. J. \& Johnson, S. (2005). Effects of sublethal UVA irradiation on activity levels of oxidative defence enzymes and protein oxidation in Escherichia coli. J Photochem Photobiol B 81, 171-180.

Imlay, J. A. (2009). Oxidative stress, Module 5.4.4. In EcoSal. Edited by J. Foster. Washington, DC: American Society for Microbiology.

Jiang, Y., Rabbi, M., Kim, M., Ke, C., Lee, W., Clark, R. L., Mieczkowski, P. A. \& Marszalek, P. E. (2009). UVA generates pyrimidine dimers in DNA directly. Biophys J 96, 1151-1158.

John, R. A. (2002). Photometric assays. In Enzyme Assays, pp. 49-78. Edited by R. Eisenthal \& M. J. Danson. Oxford: Oxford University Press.

Kohanski, M. A., Dwyer, D. J., Hayete, B., Lawrence, C. A. \& Collins, J. J. (2007). A common mechanism of cellular death induced by bactericidal antibiotics. Cell 130, 797-810.

Komanapalli, I. R., Mudd, J. B. \& Lau, B. H. S. (1997). Effect of ozone on metabolic activities of Escherichia coli K-12. Toxicol Lett 90, 6166.

Kunert, K. J., Cresswell, C. F., Schmidt, A., Mullineaux, P. M. \& Foyer, C. H. (1990). Variations in the activity of glutathione reductase and the cellular glutathione content in relation to sensitivity to methylviologen in Escherichia coli. Arch Biochem Biophys 282, 233 238. 
Latch, D. E. \& McNeill, K. (2006). Microheterogeneity of singlet oxygen distributions in irradiated humic acid solutions. Science 311, 1743-1747.

Levine, R. L. (2002). Carbonyl modified proteins in cellular regulation, aging, and disease. Free Radic Biol Med 32, 790-796.

Moss, S. H. \& Smith, K. C. (1981). Membrane damage can be a significant factor in the inactivation of Escherichia coli by nearultraviolet radiation. Photochem Photobiol 33, 203-210.

Murphey, W. H., Barrie Kitto, G. \& John, M. L. (1969). Malate dehydrogenase from Escherichia coli. Methods Enzymol 13, 145-147.

Nicholls, D. G. \& Ferguson, S. (1992). Bioenergetics 3. London: Academic Press.

Niki, E., Yoshida, Y., Saito, Y. \& Noguchi, N. (2005). Lipid peroxidation: mechanisms, inhibition, and biological effects. Biochem Biophys Res Commun 338, 668-676.

Robb, F. T., Hauman, J. H. \& Peak, M. J. (1978). Similar spectra for the inactivation by monochromatic light of two distinct leucine transport systems in Escherichia coli. Photochem Photobiol 27, 465-469.

Sharma, R. C. \& Jagger, J. (1981). Ultraviolet (254-405 nm) action spectrum and kinetic studies of alanine uptake in Escherichia coli B/R. Photochem Photobiol 33, 173-177.

Switala, J. \& Loewen, P. C. (2002). Diversity of properties among catalases. Arch Biochem Biophys 401, 145-154.
Tarmy, E. M. \& Kaplan, N. O. (1968). Chemical characterization of Dlactate dehydrogenase from Escherichia coli B. J Biol Chem 243, 25792586.

Unden, G. \& Dünnwald, P. (2008). The aerobic and anaerobic respiratory chain of Escherichia coli and Salmonella enterica: enzymes and energetics, Module 3.2.2. In EcoSal. Edited by V. Stewart. Washington, DC: American Society for Microbiology.

Visick, J. E. \& Clarke, S. (1997). RpoS- and OxyR-independent induction of HPI catalase at stationary phase in Escherichia coli and identification of rpoS mutations in common laboratory strains. J Bacteriol 179, 4158-4163.

Voss, P., Hajimiragha, H., Engels, M., Ruhwiedel, C., Calles, C., Schroeder, P. \& Grune, T. (2007). Irradiation of GAPDH: a model for environmentally induced protein damage. Biol Chem 388, 583592.

Wang, Y., Hammes, F., Boon, N. \& Egli, T. (2007). Quantification of the filterability of freshwater bacteria through $0.45,0.22$, and $0.1 \mu \mathrm{m}$ pore size filters and shape-dependent enrichment of filterable bacterial communities. Environ Sci Technol 41, 7080-7086.

Wegelin, M., Canonica, S., Mechsner, K., Fleischmann, T., Pesaro, F. \& Metzler, A. (1994). Solar water disinfection: scope of the process and analysis of radiation experiments. Aqua 43, 154-169.

Edited by: D. M. Gordon 